\title{
Chelmsford Borough Council: A designated International Safe Community
}

Commonwealth Journal of Local Governance

Issue 7: November 2010

http:/lepress.lib.uts.edu.au/ojs/index.php/cjlg

\begin{abstract}
Averil Price
Director of Safer Communities

Chelmsford Borough Council

Essex, UK
\end{abstract}

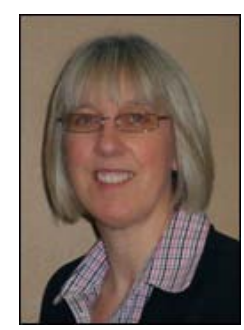

\section{Introduction}

This article provides some background to the Safe Communities concept and sets out the criteria to be satisfied as an International Safe Community (ISC). It concludes with reflections about Chelmsford Borough Council's responsibilities as a Demonstration Site within the UK, and how Council has contributed within an International Network.

There are currently over 200 communities across the world that have been designated as International Safe Communities by the World Health Organisation (WHO), and in June 2010, the Chelmsford Borough Council became the first local authority area to achieve this recognition in the UK. International Safe Communities is a World Health Organisation initiative that recognises safety as a 'universal concern and a responsibility for all'. ${ }^{1}$ It is an approach to community safety that encourages greater cooperation and collaboration between a range of non-government organisations, the business sector and local and government agencies. In order to be designated as an ISC, communities are required to meet six criteria developed by the WHO Collaborating Centre on Community Safety. ${ }^{2}$ The ISC

\footnotetext{
${ }^{1}$ Manifesto for Safe Communities. Safety - A Universal Concern and Responsibility for All. Adopted in Stockholm 20 September 1989. <www.phs.ki.se/csp/pdf/Manifesto.pdf>.

${ }_{2}$ Based at the Karolinska Institute for Social Medicine in Stockholm, Sweden.
} 
accreditation process provides support for communities and indicates a level of achievement by an organisation within the field of community safety.

\section{Defining a safe community}

The Safe Communities concept emerged from the first World Conference on Accident and Injury Prevention held in Stockholm in September 1989, accompanied by a Manifesto for the international Safe Communities movement. ${ }^{3}$ Many people and organisations worldwide invest energy and resources into the goals of achieving safe communities. The concept acknowledges that no single approach to injury prevention and safety promotion can be as effective as a collaborative approach between local organisations and the local community. Furthermore it recognises that the leading role is played by the community itself. The Safe Community initiative differs in comparison to other injury prevention programs because the leading role is played by the community itself. The term Safe Community implies that the community aspires to safety in a structured approach. ${ }^{4}$

Any community that can document a systematic approach to defining local injury prevention and safety issues, a collaborative process to address them, and a commitment to evaluate the effectiveness of their efforts are eligible to be designated as a Safe Community. ${ }^{5}$

\section{Chelmsford's Designation}

Chelmsford Council's designation as the first Safe Community in the UK provides recognition to a number of activities delivered by its own community safety program, the Safer Chelmsford Partnership. These include:

- Chelmsford Street Pastors: An inter-denominational Church response to urban problems, engaging with people on the streets to offer care and listen. It was pioneered in London in 2003 and has seen some remarkable results. Working out of a base at Chelmsford Cathedral, Chelmsford Street Pastors (inter-dominational Church response) have 86 volunteers where two or three prayer team members

\footnotetext{
3 Ibid.

${ }^{4}$ WHO Collaborating Centre on Community Safety Promotion website viewed November 2010

$<$ http://www.phs.ki.se/csp/who_introduction_en.htm>.

5 Following Lidkoping (Sweden) becoming the first Safe Community in 1989, many communities have been formally designated Safe Communities with populations ranging from 1,000 (Northcott, Australia) to over 2 million in Dallas, USA.
} 
support a street-based team each Friday and Saturday evening patrolling between 10pm and 4am. In their first year of operation, anti-social behaviour in the town centre fell by 30 per cent. They helped around 2,000 people and have contributed greatly to the safety of residents and visitors enjoying Chelmsford’s nighttime economy.

- Chelmsford Publink and Behave or Be Banned (B.O.B.B.) scheme: A partnership forged between licensed premises in Chelmsford town centre, Chelmsford Borough Council and Essex Police covering thirty four licensed premises. In its first full year of operation the partnership led to 118 police interventions for a variety of offences involving drugs and alcohol. Potential troublemakers can be dealt with quickly, and a successful 'Behave or Be Banned' mechanism ensures that known unwanted patrons are excluded from all participating venues between three months and three years, depending on the severity of their anti-social behaviour. The length of each ban is decided between the licensees, Essex Police and the Borough Council.

- Community Wheels: A project funded through partnership grants received by the Essex Casualty Reduction Board from the Department of Transport in 2007. It is an integral part of Chelmsford's strategy to reduce the number of what is termed 'killed and seriously injured' (KSI) casualties, and enables the Chelmsford Road Safety Officer to engage with local communities and groups with specific accident problems. In addition, a ‘Community Wheels’ vehicle is equipped to target a variety of audiences in diverse locations to discuss specific local issues via audiovisual education resources and a driving simulator, along with response measurement and hazard perception equipment. It was also designed to provide access for disabled visitors. Some campaigns from this Safer Chelmsford Partnership activity include discouraging young men from speeding; advice for older drivers on safe driving and provision of eye and speed reaction tests, and a car maintenance and driving project aimed at young people to discourage offending.

In the designation process, the WHO's 'Indicators for International Safe Communities' (figure 1) ensure that internationally Safe Community organizations share common goals and 
objectives. Since January 2009, applicants have had to demonstrate their capacity to meet a minimal set of activities for each indicator.

Figure 1: Indicators for International Safe Communities

I ndicators for I nternational Safe Communities

Communities in a Safe Community Setting have:

- An infrastructure based on partnership and collaborations, governed by a crosssectional group that is responsible for safety promotion in the community

- $\quad$ Long-term sustainable programmes covering both genders and all ages, environments and situations

- $\quad$ Programmes that target high-risk groups and environments and programmes that promote safety for vulnerable groups

- $\quad$ Programmes that document the frequency and cause of injuries

- $\quad$ Evaluation measures to assess programmes, processes and effects of changes

- Ongoing participation in national and international Safe Communities networks

Source: Collaborating Centre on Community Safety Promotion,

<www.phs.ki.se/csp/pdf/indicators 2004/indicators for international safe communities.pdf>

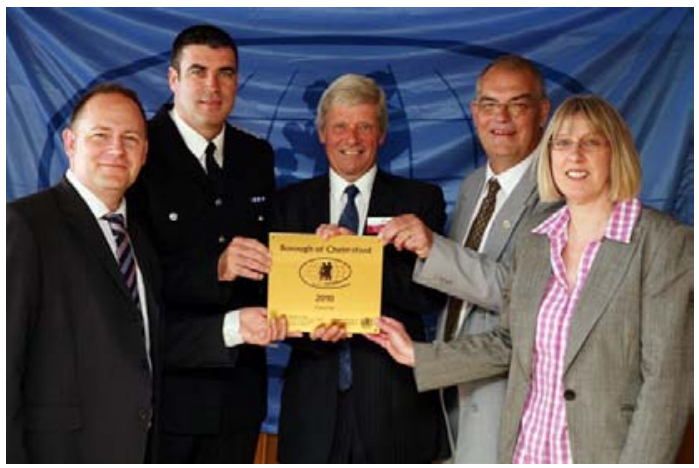

Receiving the WHO Safe Community award are (from left) Chelmsford Borough Council (CBC) Community Safety Manager Spencer Clarke; Chelmsford District Commander, Chief Inspector Joe Wrigley, CBC Cabinet Member for Safer Communities Cllr lan Grundy; WHO senior adviser Bo Henricson and CBC Director of Safer Communities Averil Price.

\section{Chelmsford as a Demonstration Site}

Chelmsford Council acknowledges that the WHO designation is the beginning of the ongoing process of becoming a safe community. Council's Safer Chelmsford Partnership has embraced its designation as a platform for future achievements, and a way to objectively recognise past successes and acknowledge Council's future work in this area. As such, Council views itself as a demonstration site that can facilitate and support other communities within the UK along the pathway to designation, ${ }^{6}$ and is continually seeking opportunities to

${ }^{6}$ Discussions are underway with the Partnership Development Unit at the Home Office to raise the profile of the International Safe Communities movement within the UK with Chelmsford as a flagship authority. 
share what we have learned about promoting safety in our Borough with existing and potential Network members. ${ }^{7}$

The Safe Community Network recognises the fundamental role played by the community itself, an entity that is larger than any of its parts. This concept fits well with the UK's Coalition Government's 'Big Society' agenda to empower communities: '... we need to create... neighbourhoods who are in charge of their own destiny, who feel if they club together and get involved they can shape the world around them' ${ }^{8}$ High on the agenda for consideration is also the potential to create a Certifying Centre within the UK that can take the lead in overseeing future designations of other communities. Chelmsford Council's involvement in the Network helps to raise the profile of its community programs locally which increases public confidence and provides reassurance to local residents. It also enables local partnerships to gain international recognition for good practice and to share their experiences and knowledge with others internationally. The application itself provides partners with a useful reference document detailing their work and identifying priorities for the future.

\section{Conclusions}

Chelmsford intends to play its part in exploring how we can continue developing and renewing the Safe Community concept and practice. As a Demonstration Site, Chelmsford is keen to share experiences and help other areas in the UK to involve their communities in promoting safety and preventing injuries in their localities. With the Big Society agenda focused on giving communities more powers and encouraging people to take an active role in their communities, this programme provides an excellent framework for priorities to be developed locally and shared internationally.

\footnotetext{
${ }^{7}$ Further lessons will emerge from the 20th International Conference on Safe Communities in Falun, Dalarna September 2011.

8 Transcript of a speech by the Prime Minister David Cameron on the Big Society, 19 July 2010

$<$ www.number10.gov.uk/news/speeches-and-transcripts $>$.
} 